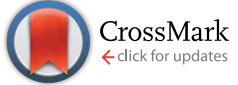

Cite this: RSC Adv., 2017, 7, 10601

Received 29th December 2016 Accepted 2nd February 2017

DOI: $10.1039 / c 6 r a 28832 d$

rsc.li/rsc-advances

\section{Podophyllotoxin-pterostilbene fused conjugates as potential multifunctional antineoplastic agents against human uveal melanoma cells}

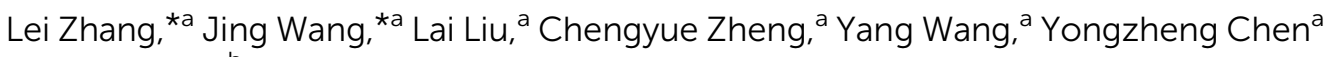 \\ and Gang Wei ${ }^{b}$
}

\begin{abstract}
Uveal melanoma is the most common primary intraocular malignancy with a high tendency for early metastasis. There is an urgent need for novel anticancer agents for the therapy of uveal melanoma. In this paper, two novel conjugates of podophyllotoxin-pterostilbene were prepared and evaluated for their cytotoxicity against human uveal melanoma cells (MUM-2B and C918) by the CCK-8 assay. Conjugate $\mathrm{B} 1$ exhibited a significant $\mathrm{IC}_{50}$ value of $0.081 \pm 0.004 \mu \mathrm{M}$ against MUM-2B cells. Treatment of MUM-2B cells with B1 caused S cell cycle arrest through reductions in CyclinB1, CDK1 and CDK2 levels. In addition, B1 showed antimigratory activity by down-regulating the expression of VEGFR-2 and MMP-2, and up-regulating the level of E-cadherin. Furthermore, B1 treatment resulted in the induction of apoptosis as characterized by Hoechst 33342 staining, flow cytometry and cleavage of procaspases-3, -8 , and -9 . Finally, B1 significantly inhibited TOPOIl $\alpha$ and TOPOII $\beta$ expression, simultaneously suppressing the ERK1/2 and AKT pathways in MUM-2B cells.
\end{abstract}

\section{Introduction}

Uveal melanoma, a rare form of melanoma, is the most frequent primary intraocular malignancy in adults. ${ }^{1}$ Unfortunately, uveal melanoma has a high tendency for early metastasis, especially spreading hematogenously to the liver. $^{2}$ Meanwhile, uveal melanoma cells are highly resistant to antineoplastic drugs. ${ }^{3}$ Untill now, there are lack of effective treatments for uveal melanoma. Therefore, there is an urgent need for novel anticancer agents for the therapy of uveal melanoma patients. ${ }^{4}$

Natural products have been widely and successfully used in treating multiple diseases, such as carcinoma., ${ }^{5,6}$ Podophyllotoxin (PPT, 1, Fig. 1), a well-known non-alkaloid toxin lignan exhibiting
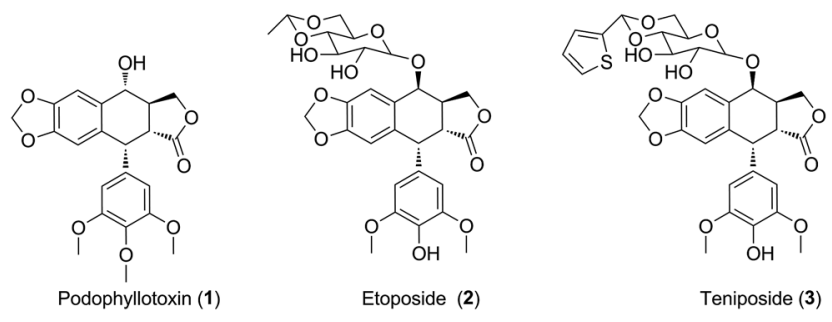

Fig. 1 The structures of podophyllotoxin and its analogues.

${ }^{a}$ School of Pharmacy, Zunyi Medical University, 201 Dalian Road, Zunyi 563003, P. R. China.E-mail: lzhang@zmc.edu.cn; wangjing@zmc.edu.cn

${ }^{b}$ CSIRO Manufacturing Flagship, PO Box 218, Lindfield, NSW 2070, Australia great anti-tumor activity by inhibiting tubulin polymerization, ${ }^{7}$ is isolated from Podophyllum hexandrum., ${ }^{8,9}$ However, due to unacceptable toxic side effects (e.g., myelosuppression, liver injury and neutropenia), it is unable to be applied in cancer treatment. ${ }^{10}$ To overcome the faults, numerous structural modifications of podophyllotoxin have been undertaken to generate some analogs with better pharmacological characters, ${ }^{11}$ such as etoposide (2, Fig. 1) and teniposide (3, Fig. 1), which are used for the treatment of small-cell lung cancer, leukaemia, neuroblastoma and nonHodgkin's lymphoma. ${ }^{12}$ In recent years, hundreds of derivatives have been synthesized from the skeleton of PPT, with higher antineoplastic profiles, such as GL-331, QS-ZYX-1-61 and Tafluposide. ${ }^{13}$ Notably, several researchers showed that PPT and its derivatives presented cytotoxicity in skin melanoma. For instance, Kamal et al. reported that PPT and its derivatives displayed significant antiproliferative activity against A375 and B16 skin melanoma cells. ${ }^{\mathbf{1 4 , 1 5}}$ However, whether PPT and its derivatives exert antitumor effect in uveal melanoma remains unclear.

Inspired by the molecules hybridization concept, ${ }^{\mathbf{1 6}}$ in this study, we described the design of two novel podophyllotoxin conjugates, with the natural product pterostilbene (trans-3,5dimethoxy-4'-hydroxystilbene, PTS, 4, Fig. 2), ${ }^{17,18}$ a dimethylated analog of resveratrol (5, Fig. 2). PTS, existed in many fruits (such as blueberries and vaccinium berries), showed diverse pharmacological properties, ${ }^{19-24}$ including anticancer, antioxidant, antidiabetic, hypolipidemic activities and anti-inflammation. It was further confirmed that PTS had no toxic effect on mice at high does. ${ }^{25}$ Additionally, previous studies reported that PTS possessed anticarcinogenic activity against skin melanoma cells. ${ }^{26,27}$ 

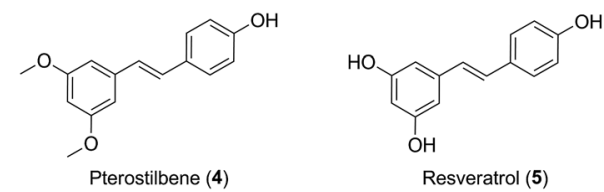

Fig. 2 Examples of pterostilbene and resveratrol.

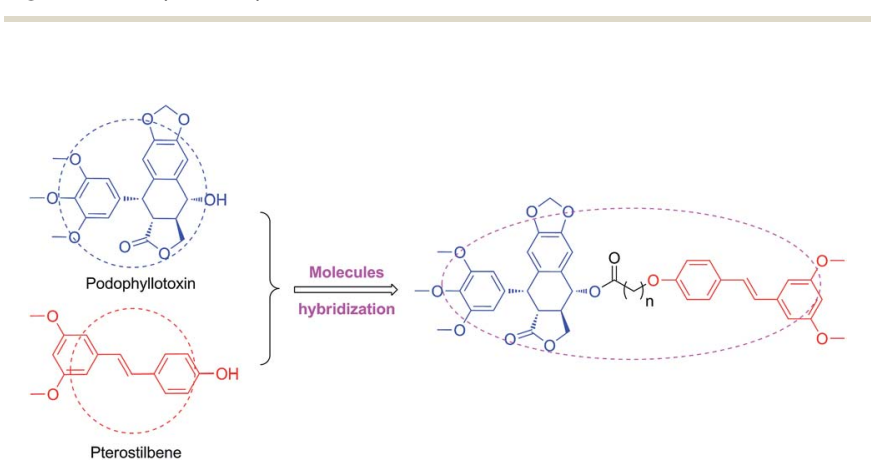

Fig. 3 Design of targeted molecules.

It's well known that PPT shows significant cytotoxicity in both of cancer and normal cells. Therefore, it is an urgent need to solve the toxicity issue of PPT. To reduce the toxicity of PPT and find new multifunctional antineoplastic agents based on the PPT skeleton in our group, ${ }^{28-30}$ here we reported the design, synthesis and antiproliferative activity of novel podophyllotoxin-pterostilbene conjugates using molecules hybridization (Fig. 3) in human uveal melanoma cells (MUM-2B and C918), simultaneously, the underlying molecular mechanisms were also investigated.

\section{Results and discussion}

The hybrid compounds (B1 and B2) were synthesized as shown in Scheme 1. Firstly, PPT was reacted with chloroacetyl chloride or 3-chloropropionyl chloride to provide the intermediates 6 or 7. Then, compounds 6 or 7 were reacted with PTS in the presence of potassium carbonate and potassium iodide to give the target molecules B1 or B2. The structures of podophyllotoxinpterostilbene conjugates were confirmed by ${ }^{1} \mathrm{H}$ NMR, ${ }^{13} \mathrm{C}$ NMR and HR-MS.

The novel podophyllotoxin-pterostilbene conjugates B1 and B2 were tested by CCK-8 assay for their in vitro antineoplastic

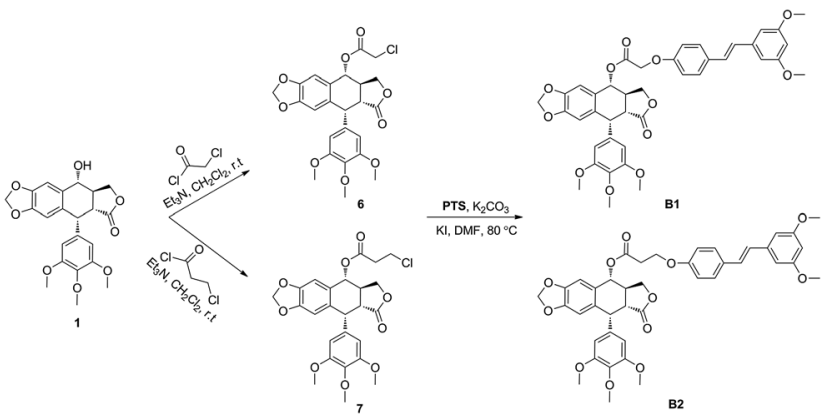

Scheme 1 Synthesis of podophyllotoxin-pterostilbene conjugates.
Table 1 Antiproliferative activity of the podophyllotoxin-pterostilbene conjugates

\begin{tabular}{lccc}
\hline & $\mathrm{IC}_{50}{ }^{a}(\mu \mathrm{M})$ & & \\
\cline { 2 - 4 } Compound & MUM-2B & C918 & HUVEC \\
\hline B1 & $0.081 \pm 0.004$ & $0.347 \pm 0.054$ & $0.362 \pm 0.109$ \\
B2 & $0.613 \pm 0.307$ & $1.035 \pm 0.152$ & $2.265 \pm 0.862$ \\
PPT & $0.016 \pm 0.006$ & $0.012 \pm 0.002$ & $0.018 \pm 0.008$ \\
PTS & $40.314 \pm 9.862$ & $68.124 \pm 7.422$ & $80.809 \pm 15.742$ \\
Etoposide & $1.965 \pm 0.221$ & $1.279 \pm 0.221$ & $2.255 \pm 0.224$ \\
\multicolumn{4}{l}{ Data were expressed as mean $\mathrm{IC}_{50} \pm \mathrm{SD}(\mu \mathrm{M})$ from three independent } \\
experiments. & & &
\end{tabular}

activity against human uveal melanoma cells (MUM-2B and C918) and human umbilical vein endothelial cells (HUVEC). PPT, PTS and clinical drug etoposide were used as positive compounds. The results were summarized in Table 1 . All tested molecules displayed potent cytotoxicity. Positive compound PPT exhibited nonspecific cytotoxicity against MUM-2B, C919 and HUVEC cells with $\mathrm{IC}_{50}$ values of $0.016 \pm 0.006,0.012 \pm$ 0.002 and $0.018 \pm 0.008 \mu \mathrm{M}$, respectively, which showed that PPT not only had strong antiproliferative activity, but also possessed high toxicity. In addition, PTS showed weaker cytotoxic activity than etoposide against above three cells with $\mathrm{IC}_{50}$ values ranging from $40.314 \pm 9.862$ to $80.809 \pm 15.742 \mu \mathrm{M}$. Interesting, hybrid compounds $\mathbf{B} 1$ and $\mathbf{B 2}$ showed significant antiproliferative activity compared with PTS. Our data showed that conjugates $\mathbf{B} 1$ and $\mathbf{B} 2$ displayed less cytotoxic activity than PPT, which may be involved with the solubility property. In addition, B1 showed better anticancer effect against MUM-2B $(0.081 \pm 0.004 \mu \mathrm{M})$ than C918 cells $(0.347 \pm 0.054 \mu \mathrm{M})$, showing 497- and 196-fold more cytotoxic than that of PTS $(40.314 \pm 9.862$ and $68.124 \pm 7.422 \mu \mathrm{M})$, respectively. Moreover, the $\mathrm{IC}_{50}$ value of $\mathbf{B} 1$ against human normal HUVEC cells was $0.362 \pm 0.109 \mu \mathrm{M}$ which was less cytotoxicity than that of PPT, indicating that conjugate had less toxicity. From the data of B1 and $\mathbf{B} 2$, conjugate displayed less anticancer activity with longer linker, at the same time, exhibited less toxicity. It was found that MUM-2B cells were more sensitive to conjugate as well as PTS than C918 cells. Furthermore, the solubility property and more details in the structure-activity relationship need further study.

To investigate the effect of $\mathbf{B} 1$ on the cell cycle, MUM-2B cells were treated with $0.1 \mu \mathrm{M} \mathrm{B1}$ for $48 \mathrm{~h}$, and then analyzed by flow cytometry. PPT and PTS were used as positive compounds. As shown in Fig. 4, after treatment with $0.1 \mu \mathrm{M} \mathrm{B1}, 77.69 \%$ of cell numbers were accumulated in S phase, compared with $16.54 \%$ cells accumulation in S phase in control group. Meanwhile, the percentages of cells in S phase were $81.42 \%$ and $74.11 \%$, respectively, in $0.01 \mu \mathrm{M}$ PPT and $50 \mu \mathrm{M}$ PTS-treated groups. It was revealed that conjugate B1 could induce MUM-2B cells arrest at $\mathrm{S}$ phase.

Next, to validate whether the inhibitory effect of B1 on MUM2B cells proliferation are accompanied by apoptosis, MUM-2B cells were treated with $0.1 \mu \mathrm{M} \mathrm{B1}$ for $48 \mathrm{~h}$, and the apoptotic cells were analyzed by flow cytometry. PPT and PTS were used as positive compounds. We observed that the rate of apoptosis 

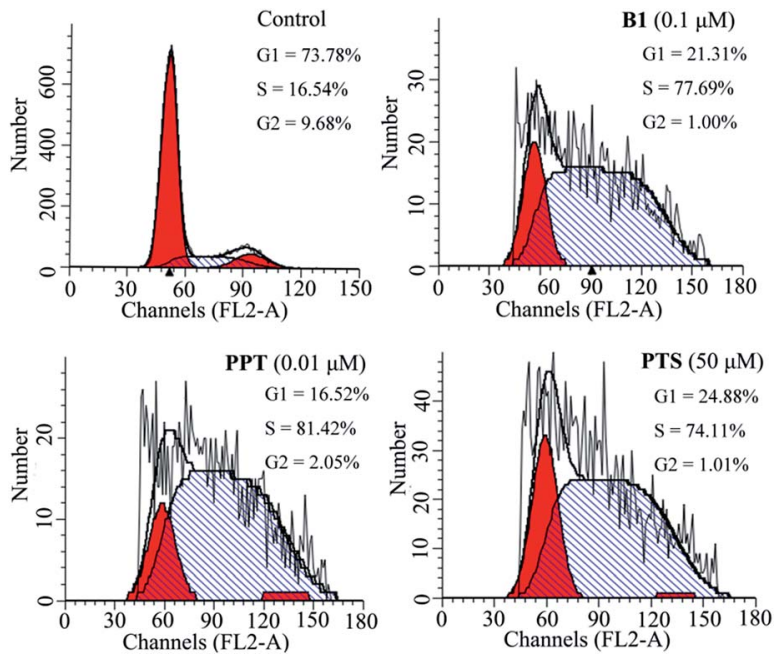

Fig. 4 Effects of conjugate B1, PPT and PTS on the cycle of MUM-2B cells. Cells were treated with vehicle, $0.1 \mu \mathrm{M}$ B1, $0.01 \mu \mathrm{M}$ PPT or $50 \mu \mathrm{M}$ PTS for $48 \mathrm{~h}$.

in $0.1 \mu \mathrm{M}$ B1-treated group was $37.72 \%$ (Fig. 5), which were stronger than that of the control group (4.16\%). Similarly, apoptotic cell number increased to $32.95 \%$ and $48.73 \%$ when the cells were incubated with $0.01 \mu \mathrm{M}$ PPT and $50 \mu \mathrm{M}$ PTS, respectively. These results indicated that conjugate $\mathbf{B 1}$ could induce apoptosis in MUM-2B cells.

Furthermore, to confirm the induction of apoptosis of B1, MUM-2B cells were tested by Hoechst 33342 staining. As seen in Fig. 6, treatment with $0.1 \mu \mathrm{M}$ B1 led to cell shrinkage and chromatin condensation. Meanwhile, bright blue fluorescent and condensed nuclei in apoptosis cells were observed by treatment with $0.1 \mu \mathrm{M}$ B1. Similar effects were observed when cells were incubated with $0.01 \mu \mathrm{M}$ PPT and $50 \mu \mathrm{M}$ PTS. There were no significant characteristics of apoptosis in
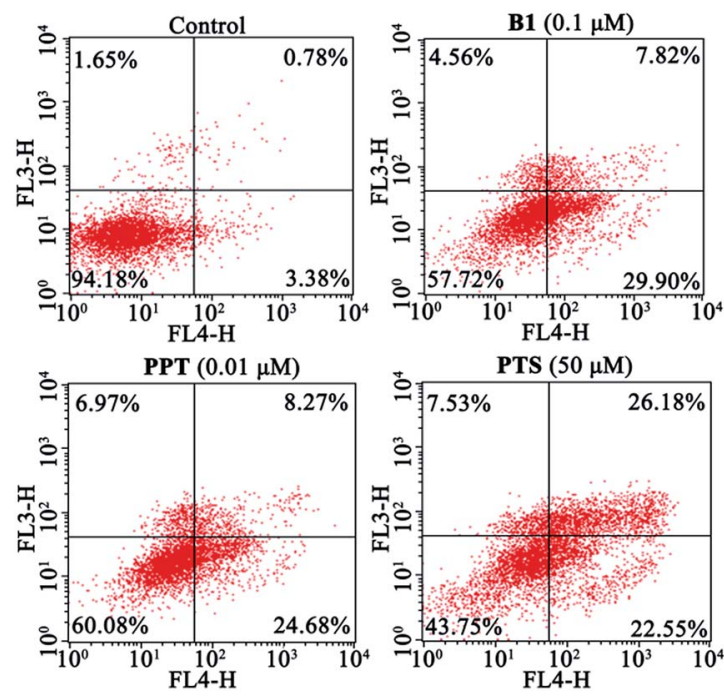

Fig. 5 Effects of conjugate B1, PPT and PTS on the apoptosis of MUM2B cells. Cells were treated with vehicle, $0.1 \mu \mathrm{M}$ B1, $0.01 \mu \mathrm{M}$ PPT or 50 $\mu \mathrm{M}$ PTS for $48 \mathrm{~h}$. control group. The above results significantly proved that conjugate B1 was effective in inducing MUM-2B cells apoptosis.

Recently, some studies reported that PPT and PTS both had the potential to suppress tumor migratory and metastasis. ${ }^{31-33}$ To further test the effect of conjugate B1 on the migration potential of cancer cells, wound healing assay was conducted on MUM-2B cells in vitro. As shown in Fig. 7, after treatment with $0.1 \mu \mathrm{M}$ B1, $0.01 \mu \mathrm{M}$ PPT or $50 \mu \mathrm{M}$ PTS for $24 \mathrm{~h}$, the migration of MUM-2B cells was suppressed obviously, compared with the control group. These data indicated that conjugate B1 might have the potential to inhibit the migratory and metastasis of MUM-2B cells.

To evaluate the mechanisms involved in $\mathrm{S}$ cell cycle arrest in MUM-2B cells, the effects of $\mathbf{B} 1$ on expression of cell cyclerelated proteins were examined by western blotting using PPT and PTS as positive compounds. As shown in Fig. 8A, $0.1 \mu \mathrm{M}$ B1 significantly decreased the expression levels of CDK1, CDK2 and CyclinB1, compared with the vehicletreated control, however, CyclinA level in MUM-2B cells was not changed. Similar effects were observed when cells were incubated with $0.01 \mu \mathrm{M}$ PPT and $50 \mu \mathrm{M}$ PTS. Taken together, these data proved that conjugate B1 blocked MUM$2 \mathrm{~B}$ cells in the $\mathrm{S}$ phase by down-regulation of CDK1, CDK2 and CyclinB1.

In order to further investigate the mechanisms involved in apoptosis induced by B1, the expression of apoptotic proteins (the cleavage states of caspase 3, 8 and 9) in MUM-2B cells was examined by western blotting (Fig. 8B). PPT and PTS were used as positive compounds. The data revealed that $0.1 \mu \mathrm{M}$ B1treatment dramatically increased the relative levels of cleaved caspase 3, 8 and 9 in MUM-2B cells. Similar effects were observed when cells were incubated with $0.01 \mu \mathrm{M}$ PPT and 50 $\mu \mathrm{M}$ PTS. Collectively, these findings strongly demonstrated that conjugate B1-induced apoptosis of MUN-2B cells was mediated by signaling cascade of apoptosis.

Our above findings showed that conjugate B1 possessed antimigratory activity in MUM-2B cells. Furthermore, Vascular Endothelial Growth Factor Receptor 2 (VEGFR-2), Matrix Metalloproteinase-2 (MMP-2) and E-cadherin are crucial events of invasion and metastasis in malignant cancer cells. $^{34-36}$ Thus, we next further assess the roles of above metastasis-related proteins in B1-treated MUM-2B cells by western blotting. As shown in Fig. 9A, treatment with $0.1 \mu \mathrm{M}$ B1 significantly increased the expression level of E-cadherin, simultaneously, down-regulated the levels of VEGFR-2 and MMP-2 in MUM-2B cells, compared with the control group. Interestingly, the levels of VEGFR-2 and E-cadherin were not altered by $0.01 \mu \mathrm{M}$ PPT, whereas, $50 \mu \mathrm{M}$ PTS did, suggesting that the antimigratory activity of $\mathbf{B 1}$ was related with the structure of PTS. These findings suggested that the antimigratory effect of conjugate B1 was mediated by VEGFR-2, MMP-2 and E-cadherin.

Ren et al. demonstrated that PPT derivative could inhibit the expression of DNA topoisomerase II $\alpha$ in HepG2 cells. ${ }^{37}$ Consequently, we next investigated the effects of $\mathbf{B 1}$ on the DNA topoisomerase II $\alpha$ (TOPOII $\alpha$ ) and DNA topoisomerase II $\beta$ 

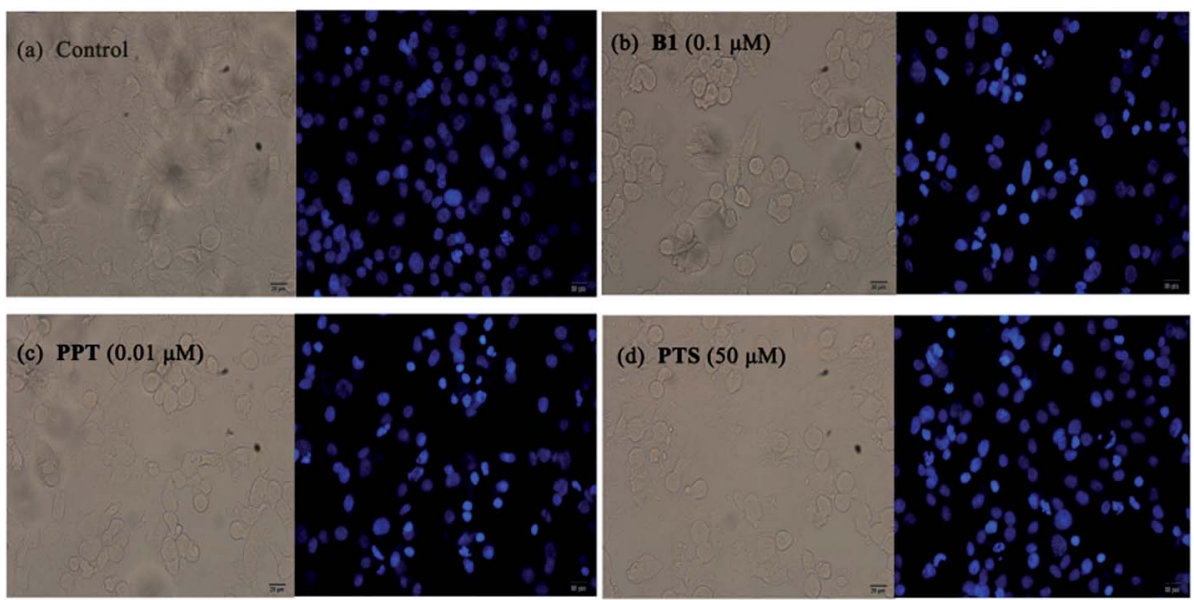

Fig. 6 Effects of conjugate B1, PPT and PTS on the morphology of MUM-2B cells. Cells were treated with vehicle, $0.1 \mu \mathrm{M}$ B1, $0.01 \mu \mathrm{M}$ PPT or 50 $\mu \mathrm{M}$ PTS for $24 \mathrm{~h}$, then stained with Hoechst 33342 for microscopy. (a) Control group; (b) $0.1 \mu \mathrm{M}$ B1; (c) $0.01 \mu \mathrm{M}$ PPT; (d) $50 \mu \mathrm{M}$ PTS. Magnification: $200 \times$, scale $20 \mu \mathrm{m}$.

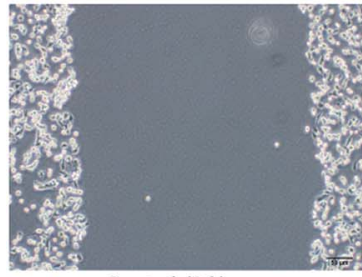

Control $(0 \mathrm{~h})$

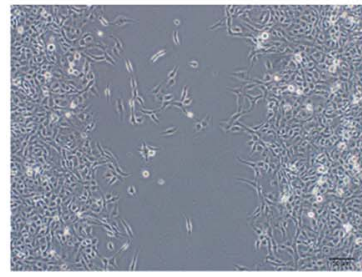

PPT $(0.01 \mu \mathrm{M})$

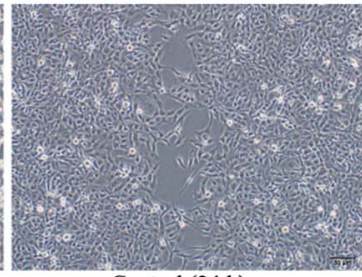

Control $(24 \mathrm{~h})$

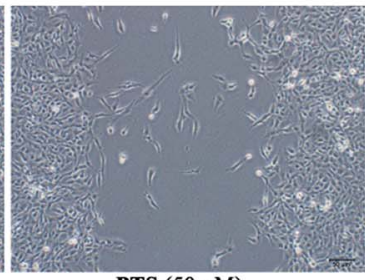

PTS $(50 \mu \mathrm{M})$

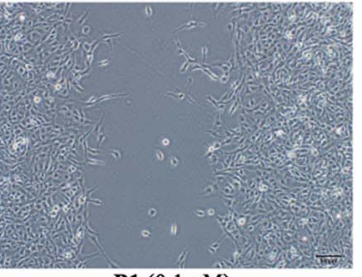

B1 $(0.1 \mu \mathrm{M})$

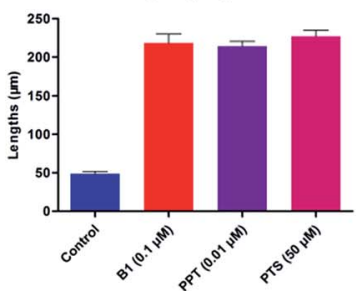

Fig. 7 Effects of conjugate B1, PPT and PTS on the migration of MUM-2B cells in vitro. Cells were treated with vehicle, $0.1 \mu M$ B1, $0.01 \mu M$ PPT or $50 \mu \mathrm{M}$ PTS for $24 \mathrm{~h}$. Columns mean and bars given here follow \pm SD of three independent experiments. Magnification: $100 \times$, scale $50 \mu \mathrm{m}$.

(TOPOII $\beta$ ) proteins expression by western blotting. As shown in Fig. 9B, $0.1 \mu \mathrm{M}$ B1 demonstrated the ability to decrease the expression of TOPOII $\alpha$ and TOPOII $\beta$ in MUM-2B cells. Similar effect was observed when cells were incubated with $0.01 \mu \mathrm{M}$ PPT. Interestingly, $50 \mu \mathrm{M}$ PTS could down-regulate the TOPOII $\alpha$ expression level, while, increase the expression of TOPOII $\beta$. Collectively, the results indicated that conjugate B1 could lower the expression levels of TOPOII $\alpha$ and TOPOII $\beta$ in MUM-2B cells.

It was reported that PTS showed anti-inflammatory and anticarcinogenic activity by inhibition of COX-2 and iNOS. ${ }^{\mathbf{3 8 - 4 0}}$ Thus, the expression of inflammatory-related proteins in B1treated MUM-2B cells was performed by western blotting. As seen in Fig. 9C, treatment with $0.01 \mu \mathrm{M}$ B1 could not alter the expression levels of COX-2 and iNOS in MUM-2B cells. Similar effect was observed in $0.01 \mu \mathrm{M}$ PPT group. However, $50 \mu \mathrm{M}$ PTS could down-regulate the COX-2 level. The results confirmed that the cytotoxic activity of conjugate B1 against MUM-2Bcells might not be mediated by COX-2 and iNOS.

More recently, we showed that PPT and its analogue could stimulate the ERK1/2 pathway in K562/adr cells. ${ }^{41}$ To further clarify the molecular mechanisms underlying the activity of B1, we finally investigated the effects of B1 on the ERK1/2, AKT and STAT3 signaling in MUM-2B cells. Cells were treated with vehicle, $0.1 \mu \mathrm{M}$ B1, $0.01 \mu \mathrm{M}$ PPT or $50 \mu \mathrm{M}$ PTS for $48 \mathrm{~h}$. Phosphorylation of ERK1/2, AKT and STAT3 was determined by western blotting. Fig. 10 showed that treatment with $0.1 \mu \mathrm{M}$ B1 significantly suppressed the phosphorylation of ERK1/2 and AKT in MUM-2B cells, however, the phosphorylation of STAT3 was not altered, compared with the control group. Similar effects were observed when cells were treated with $0.01 \mu \mathrm{M}$ PPT and $50 \mu \mathrm{M}$ PTS. These results suggested that conjugate B1 might inhibit the activation of the ERK1/2 and AKT pathways, which contributed to its antineoplastic activity in MUM-2B cells. 

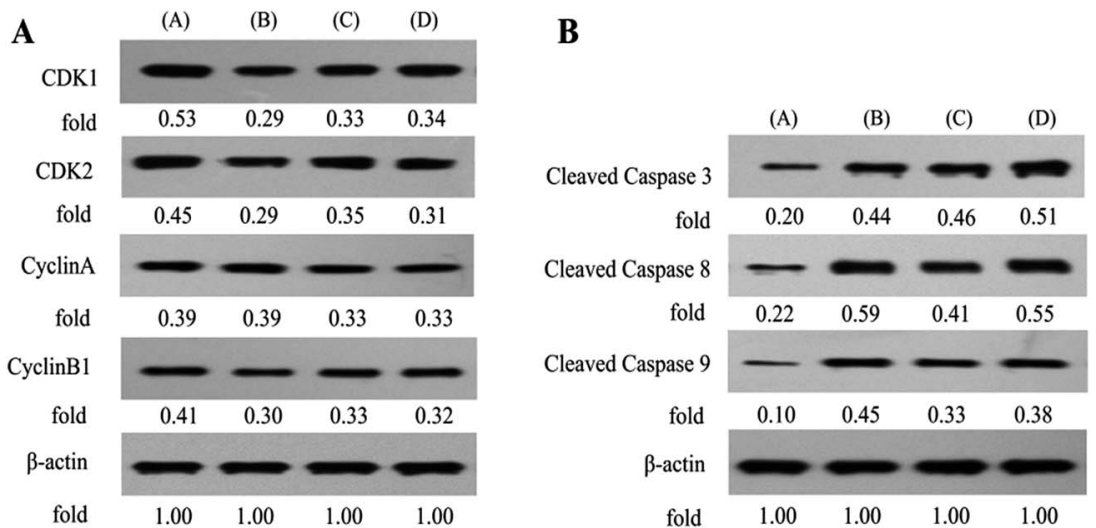

Fig. 8 Effects of conjugate B1, PPT and PTS on the cell cycle- and apoptosis-related proteins expression, respectively, in MUM-2B cells by western blotting using $\beta$-actin as a control. (A) Control MUM-2B cells; (B) MUM-2B cells treated with $0.1 \mu M$ B1; (C) MUM-2B cells treated with $0.01 \mu \mathrm{M}$ PPT; (D) MUM-2B cells treated with $50 \mu \mathrm{M}$ PTS.
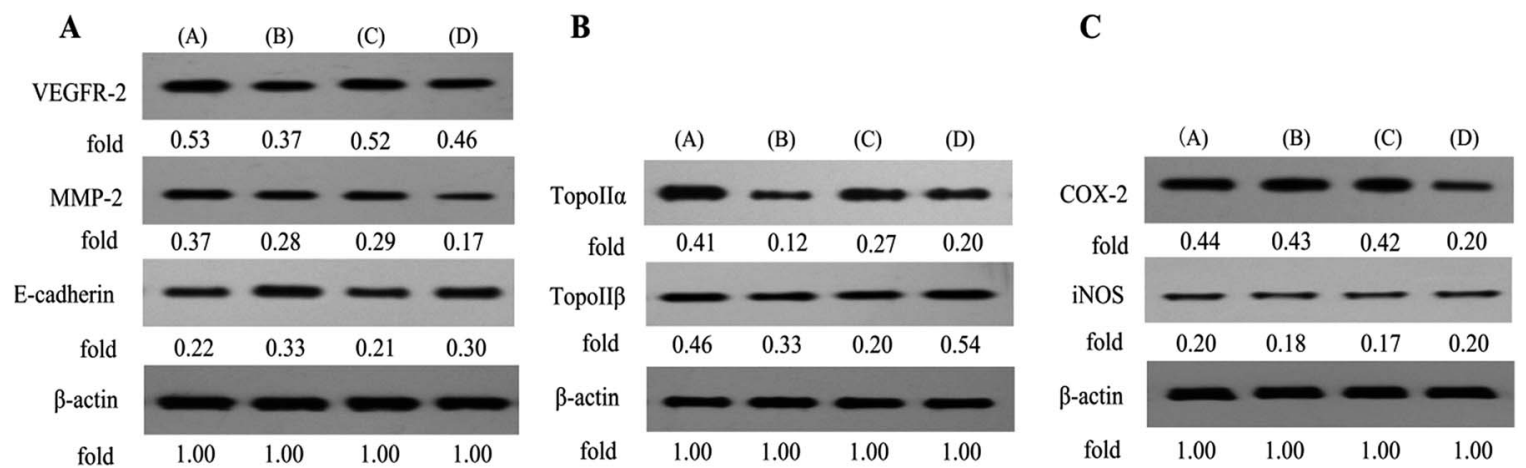

Fig. 9 Effects of conjugate B1, PPT and PTS on the metastasis-, TOPO- and inflammatory-related proteins expression, respectively, in MUM-2B cells by western blotting using $\beta$-actin as a control. (A) Control MUM-2B cells; (B) MUM-2B cells treated with $0.1 \mu M$ B1; (C) MUM-2B cells treated with $0.01 \mu \mathrm{M}$ PPT; (D) MUM-2B cells treated with $50 \mu \mathrm{M}$ PTS.

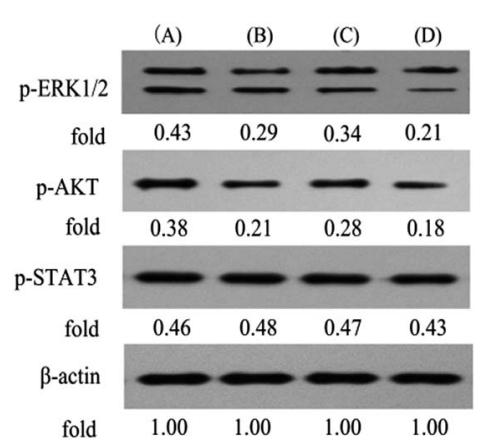

Fig. 10 Effects of conjugate B1, PPT and PTS on the ERK1/2, AKT and STAT3 signaling in MUM-2B cells by western blotting using $\beta$-actin as a control. (A) Control MUM-2B cells; (B) MUM-2B cells treated with 0.1 $\mu \mathrm{M}$ B1; (C) MUM-2B cells treated with $0.01 \mu \mathrm{M}$ PPT; (D) MUM-2B cells treated with $50 \mu \mathrm{M}$ PTS.

\section{Experimental}

\section{General}

Melting points were taken on a SGWX-4 meltingpoint apparatus. High-resolution mass spectra (HR-MS) were performed on an Agilent Accurate-Mass-Q-TOF-MS 6520. The ${ }^{1} \mathrm{H}$ and ${ }^{13} \mathrm{C}$ NMR spectra were recorded on an Agilent-NMR-vnmrs (400 $\mathrm{MHz}$ ) instrument using TMS as internal standard.

\section{Preparation of intermediates 6 and 7}

To a solution of PPT (1.9 mmol, 1 eq.) and triethylamine (4 eq.) in dry dichloromethane $(15 \mathrm{~mL})$ for at $0{ }^{\circ} \mathrm{C}$, chloroacetyl chloride or 3-chloropropionyl chloride (2.5 eq.) was added. The mixture was stirred under argon at room temperature for $1 \mathrm{~h}$. After that, the mixture was quenched with $\mathrm{NH}_{4} \mathrm{Cl}(5 \mathrm{~mL})$ for $10 \mathrm{~min}$ and extracted with dichloromethane $(3 \times 10 \mathrm{~mL})$. The combined organic phase was washed with brine, then dried over anhydrous $\mathrm{MgSO}_{4}$ and evaporated under reduced pressure. The crude was further purified by column chromatography (dichloromethane/methanol = $100: 1$ ) to give the intermediate.

Chloroacetate-4-desoxypodophyllotoxin (6). Yellowish white power, yield 90\%; mp: $219-220{ }^{\circ} \mathrm{C} ;{ }^{1} \mathrm{H}$ NMR (400 $\mathrm{MHz}, \mathrm{CDCl}_{3}$ ) $\delta 6.77(\mathrm{~s}, 1 \mathrm{H}), 6.55(\mathrm{~s}, 1 \mathrm{H}), 6.37(\mathrm{~s}, 2 \mathrm{H}), 5.99(\mathrm{~d}, J=4.8 \mathrm{~Hz}, 2 \mathrm{H})$, $5.96(\mathrm{~d}, J=8.4 \mathrm{~Hz}, 1 \mathrm{H}), 4.61(\mathrm{~d}, J=2.6 \mathrm{~Hz}, 1 \mathrm{H}), 4.38-4.42(\mathrm{~m}$, $1 \mathrm{H}), 4.13-4.24(\mathrm{~m}, 3 \mathrm{H}), 3.80(\mathrm{~s}, 3 \mathrm{H}), 3.75(\mathrm{~s}, 6 \mathrm{H}), 2.84-2.97(\mathrm{~m}$, $2 \mathrm{H}) ;{ }^{13} \mathrm{C} \mathrm{NMR}\left(100 \mathrm{MHz}, \mathrm{CDCl}_{3}\right) \delta 173.41,167.94,152.65$, 148.41, 147.70, 137.11, 134.53, 132.55, 127.21, 109.78, 107.97, 


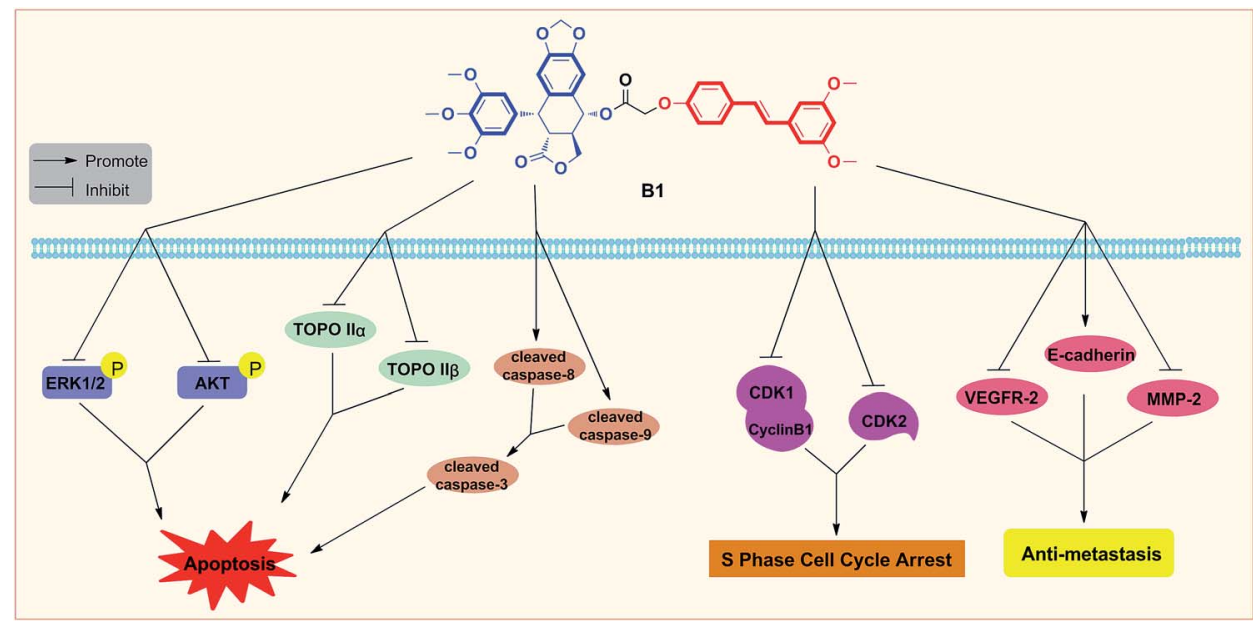

Fig. 11 Proposed diagrams of antineoplastic activity of conjugate B1 against human uveal melanoma MUM-2B cells.

106.92, 101.71, 75.64, 71.13, 60.75, 56.13, 45.52, 43.64, 40.69, 40.48, 38.46; HRMS-ESI ( $m / z)$ : calcd for $\mathrm{C}_{24} \mathrm{H}_{27} \mathrm{NClO}_{9}\left[\mathrm{M}+\mathrm{NH}_{4}\right]^{+}$ 508.1369, found 508.1367.

3-Chloropropionate-4-desoxypodophyllotoxin (7). Yellowish white power, yield $84 \%$; mp: $139-141{ }^{\circ} \mathrm{C} ;{ }^{1} \mathrm{H}$ NMR $(400 \mathrm{MHz}$, $\left.\mathrm{CDCl}_{3}\right) \delta 6.79(\mathrm{~s}, 1 \mathrm{H}), 6.55(\mathrm{~s}, 1 \mathrm{H}), 6.50(\mathrm{~d}, J=17.2 \mathrm{~Hz}, 1 \mathrm{H}), 6.40$ $(\mathrm{d}, J=4.8 \mathrm{~Hz}, 2 \mathrm{H}), 6.20(\mathrm{dd}, J=10.4,17.2 \mathrm{~Hz}, 1 \mathrm{H}), 6.00(\mathrm{~s}, 1 \mathrm{H})$, $5.98(\mathrm{~s}, 2 \mathrm{H}), 5.95(\mathrm{~s}, 1 \mathrm{H}), 4.62(\mathrm{~d}, J=4.0 \mathrm{~Hz}, 1 \mathrm{H}), 4.40(\mathrm{dd}, J=$ $7.2,9.6 \mathrm{~Hz}, 1 \mathrm{H}), 4.24(\mathrm{t}, J=9.2 \mathrm{~Hz}, 1 \mathrm{H}), 3.81(\mathrm{~s}, 3 \mathrm{H}), 3.76(\mathrm{~s}, 6 \mathrm{H})$, 2.98-2.91 (m, 2H); ${ }^{13} \mathrm{C}$ NMR $\left(100 \mathrm{MHz}, \mathrm{CDCl}_{3}\right) \delta 173.66,166.42$, 152.60, 148.15, 147.60, 134.79, 132.39, 128.19, 127.65, 109.72, 107.98, 107.06, 101.61, 73.72, 71.40, 60.76, 56.15, 56.10, 45.60, 43.72, 38.72; HRMS-ESI $(m / z)$ : calcd for $\mathrm{C}_{25} \mathrm{H}_{29} \mathrm{NClO}_{9}\left[\mathrm{M}+\mathrm{NH}_{4}\right]^{+}$ 522.1525 , found 522.1523 .

\section{Preparation of target compounds B1 and B2}

To a solution of 6 or 7 ( $0.25 \mathrm{mmol}, 1$ eq.), potassium iodide (0.01 eq.), potassium carbonate ( 1 eq.) in DMF ( $4 \mathrm{~mL}$ ), PTS (1.1 eq.) was added, and the reaction mixture was stirred under argon at $80^{\circ} \mathrm{C}$ for $1 \mathrm{~h}$. The reaction mixture was cooled, added to water, and extracted with dichloromethane $(3 \times 10 \mathrm{~mL})$. The combined organic phase was washed with brine, then dried over anhydrous $\mathrm{MgSO}_{4}$ and evaporated under reduced pressure. The crude was further purified by column chromatography (ethyl acetate/petroleum ether $=1: 2-1: 4$ ) to give targeted molecule.

(E)-4-(3,5-Dimethoxystyryl)phenyl acetate-4-desoxypodophyllotoxin (B1). White power, yield 62\%; mp: $104-105{ }^{\circ} \mathrm{C} ;{ }^{1} \mathrm{H}$ NMR $(400$ $\left.\mathrm{MHz}, \mathrm{CDCl}_{3}\right) \delta 7.45(\mathrm{~d}, J=8.8 \mathrm{~Hz}, 2 \mathrm{H}), 7.02(\mathrm{~d}, J=16.4 \mathrm{~Hz}, 1 \mathrm{H})$, $6.91(\mathrm{~d}, J=16.4 \mathrm{~Hz}, 1 \mathrm{H}), 6.89(\mathrm{~d}, J=8.4 \mathrm{~Hz}, 2 \mathrm{H}), 6.64(\mathrm{~s}, 3 \mathrm{H}), 6.52$ (s, 1H), 6.34-6.38 (m, 3H), $5.98(\mathrm{~d}, J=8.4 \mathrm{~Hz}, 2 \mathrm{H}), 5.96(\mathrm{~s}, 1 \mathrm{H})$, $4.78(\mathrm{~d}, J=4.8,2 \mathrm{H}), 4.59(\mathrm{~d}, J=3.6 \mathrm{~Hz}, 1 \mathrm{H}), 4.36-4.32(\mathrm{~m}, 1 \mathrm{H})$, $4.19(\mathrm{t}, J=9.2 \mathrm{~Hz}, 1 \mathrm{H}), 3.82(\mathrm{~s}, 6 \mathrm{H}), 3.80(\mathrm{~s}, 3 \mathrm{H}), 3.74(\mathrm{~s}, 6 \mathrm{H}), 2.93-$ $2.80(\mathrm{~m}, 2 \mathrm{H}) ;{ }^{13} \mathrm{C} \mathrm{NMR}\left(100 \mathrm{MHz}, \mathrm{CDCl}_{3}\right) \delta 173.40,169.53,160.94$, 157.12 , 152.63, 148.30, 147.61, 139.35, 137.09, 134.63, 132.45, $131.38,128.19,127.95,127.44,127.38,114.66,109.74,107.97$, 106.88, 104.37, 101.68, 99.74, 74.79, 71.11, 65.26, 60.76, 56.14,
55.36, 45.45, 43.63, 38.49; HRMS-ESI $(\mathrm{m} / \mathrm{z})$ : calcd for $\mathrm{C}_{40} \mathrm{H}_{39} \mathrm{O}_{12}[\mathrm{M}$ $+\mathrm{H}]^{+} 711.2436$, found 711.2434 .

(E)-4-(3,5-Dimethoxystyryl)phenyl propionate-4-desoxypodophyllotoxin (B2). White power, yield 57\%; mp: $205-207{ }^{\circ} \mathrm{C} ;{ }^{1} \mathrm{H}$ NMR (400 MHz, $\left.\mathrm{CDCl}_{3}\right) \delta 6.79(\mathrm{~s}, 2 \mathrm{H}), 6.56(\mathrm{~s}, 2 \mathrm{H}), 6.37(\mathrm{~s}, 3 \mathrm{H})$, $6.26(\mathrm{~d}, J=17.2 \mathrm{~Hz}, 2 \mathrm{H}), 5.97(\mathrm{~s}, 2 \mathrm{H}), 5.95(\mathrm{~s}, 2 \mathrm{H}), 5.84(\mathrm{~s}, 1 \mathrm{H})$, $5.81(\mathrm{~s}, 1 \mathrm{H}), 5.79(\mathrm{~s}, 1 \mathrm{H}), 4.47-4.41(\mathrm{~m}, 3 \mathrm{H}), 4.30(\mathrm{~d}, J=3.2 \mathrm{~Hz}$, $1 \mathrm{H}), 4.27(\mathrm{~d}, J=2.8 \mathrm{~Hz}, 1 \mathrm{H}), 3.82(\mathrm{~s}, 6 \mathrm{H}), 3.77(\mathrm{~s}, 9 \mathrm{H}), 3.33(\mathrm{dd}, J=$ 3.2, $9.2 \mathrm{~Hz}, 2 \mathrm{H}), 3.08-3.02(\mathrm{~m}, 2 \mathrm{H}) ;{ }^{13} \mathrm{C} \mathrm{NMR}\left(100 \mathrm{MHz}, \mathrm{CDCl}_{3}\right)$ $\delta$ 177.38, 165.59, 153.19, 148.47, 147.22, 138.95, 136.71, 132.19, $131.22,127.61,126.02,109.90,108.68,105.22,101.43,72.49$, 70.75, 60.81, 56.11, 45.35, 44.29, 39.61, 29.68; HRMS-ESI $(\mathrm{m} / \mathrm{z})$ : calcd for $\mathrm{C}_{41} \mathrm{H}_{41} \mathrm{O}_{12}[\mathrm{M}+\mathrm{H}]^{+}$725.2593, found 725.2589.

\section{Pharmacology}

Materials. DMSO, antibodies (except TopoII $\alpha$ and TopoII $\beta$ ), cells, PBS, CCK-8, apoptosis detection kit, cell cycle detection kit and Hoechst 33342 were purchased from KeyGen Biotech (Nanjing, China). TopoII $\alpha$ and TopoII $\beta$ were purchased from Proteintech Group (Chicago, IL). FBS was bought from ExCell Biology (Shanghai, China).

CCK-8 assay. ${ }^{42}$ MUM-2B, C918 or HUVEC cells were planted in 96-well plates for $24 \mathrm{~h}$, and then incubated with $0.1 \%$ DMSO and test compounds at the indicated concentration for $72 \mathrm{~h}$ at $37{ }^{\circ} \mathrm{C}$. Then, cells were incubated CCK-8 $(10 \mu \mathrm{L})$ for $2 \mathrm{~h}$. The absorbance was determinated at $450 \mathrm{~nm}$.

Cell cycle analysis. ${ }^{42}$ MUM-2B cells were plated in 6-well plates for $12 \mathrm{~h}$, and then incubated with $0.1 \%$ DMSO and test compounds at the indicated concentration for $48 \mathrm{~h}$. Then, cells were harvested and fixed overnight in $70 \%$ ethanol at $4{ }^{\circ} \mathrm{C}$. Subsequently, cells were washed three times with PBS, and then incubated with RNase $(100 \mu \mathrm{L})$ at $37{ }^{\circ} \mathrm{C}$ for $30 \mathrm{~min}$ and stained with propidium iodide $(400 \mu \mathrm{L})$ at $4{ }^{\circ} \mathrm{C}$ for $30 \mathrm{~min}$. The cells were measured by a flow cytometer.

Cell apoptosis assay. ${ }^{42}$ MUM-2B cells were plated in 6-well plates for $12 \mathrm{~h}$, and then incubated with $0.1 \%$ DMSO and test compounds at the indicated concentration for $48 \mathrm{~h}$. Subsequently, cells were washed twice with PBS, and then treated with Annexin 
V-APC $(5 \mu \mathrm{L})$ and 7-AAD $(5 \mu \mathrm{L})$ at room temperature for $15 \mathrm{~min}$ in the dark. Apoptotic cells were quantified using a flow cytometer.

Hoechst 33242 staining. ${ }^{42}$ MUM-2B cells incubated with $0.1 \%$ DMSO and test compounds at the indicated concentration for a period of $24 \mathrm{~h}$. Subsequently, cells were washed with PBS, and then incubated with Hoechst 33342 at room temperature for $10 \mathrm{~min}$. The cells were then observed by inverted microscope or fluorescent microscope.

Western blotting. ${ }^{42}$ After $48 \mathrm{~h}$ treatment, total protein was extracted using centrifuging at $13000 \mathrm{~g}$ at $4{ }^{\circ} \mathrm{C}$ for $10 \mathrm{~min}$, and then determined using BCA Protein Assay kit. The proteins were separated by $10 \%$ SDS-PAGE, and then transferred to a nitrocellulose membrane, which was blocked with $5 \%$ skim milk for $2 \mathrm{~h}$ and incubated with primary antibodies: CDK1, CDK2, CyclinA, CyclinB1, cleaved caspase 3, cleaved caspase 8, cleaved caspase 9, VEGFR-2, MMP-2, E-cadherin, TopoII $\alpha$, TopoII $\beta$, COX-2, iNOS, pERK1/2, p-AKT, p-STAT3 and $\beta$-actin overnight at $4{ }^{\circ} \mathrm{C}$. After washing, membranes were then treated with secondary antibodies at room temperature for $2 \mathrm{~h}$. The immunoreactive bands were visualized using enhanced chemiluminescence detection system and quantitated with using Gel-Pro32 software.

Wound healing assay. MUM-2B cells were seeded in a 6 well plate for $24 \mathrm{~h}$, and then washed with PBS to remove floated and detached cells and photographed ( $0 \mathrm{~h})$. MUM-2B cells were successively incubated with $0.1 \%$ DMSO and test compounds at the indicated concentration for $24 \mathrm{~h}$. Wounded areas were photographed under an inverted microscope (OLYMPUS, IX51) at $100 \times$ magnification.

\section{Conclusions}

In summary, two novel conjugates of podophyllotoxin-pterostilbene were synthesized and evaluated against human uveal melanoma cell lines in vitro. Compound B1 exhibited a significant $\mathrm{IC}_{50}$ value of $0.081 \pm 0.004 \mu \mathrm{M}$ against MUM-2B cells. Treatment with B1 induced MUM-2B cell cycle arrest at $S$ phase and apoptosis, as well as showed antimigratory activity. Furthermore, B1 significantly inhibited TOPOII $\alpha$ and TOPOII $\beta$ expression, simultaneously, suppressed the ERK1/2 and AKT pathways in MUM-2B cells. The antitumor mechanisms of $\mathbf{B 1}$ were presented in Fig. 11. Overall, our findings indicated that conjugate B1 might be a potent antineoplastic agent for uveal melanoma chemotherapy, however, metabolic stability evaluation and anticancer efficacy in vivo of conjugates still need our further studies.

\section{Acknowledgements}

This work was financially supported by the Department of Science and Technology of Guizhou Province (No. [2014]7565, [2014]7557, [2015]6010), Ministry of Education "Chunhui Project" Foundation of China (No. Z2015008) and Discipline Construction Funding of Zunyi Medical University.

\section{Notes and references}

1 A. D. Singh, M. E. Turell and A. K. Topham, Ophthalmology, 2011, 118, 1881-1885.
2 S. E. Coupland, S. L. Lake, M. Zeschnigk and B. E. Damato, Eye, 2013, 27, 230-242.

3 P. L. Blanco, L. A. Lim, C. Miyamoto and M. N. Burnier, Melanoma Res., 2012, 22, 334-340.

4 P. A. O'Neill, M. Butt, C. V. Eswar, P. Gillis and E. Marshall, Melanoma Res., 2006, 16, 245-248.

5 D. J. Newman and G. M. Cragg, J. Nat. Prod., 2012, 75, 311335.

6 D. J. Newman and G. M. Cragg, J. Nat. Prod., 2016, 79, 629661.

7 Y. Damayanthi and J. W. Lown, Curr. Med. Chem., 1998, 5, 205-252.

8 M. Gordaliza, P. A. García, J. M. Miguel del Corral, M. A. Castro and M. A. Gómez-Zurita, Toxicon, 2004, 44, 441-459.

9 H. Xu, M. Lv and X. Tian, Curr. Med. Chem., 2009, 16, 327349.

10 L. Bohlin and B. Rosen, Drug Discovery Today, 1996, 1, 343351.

11 Y. Q. Liu, J. Tian, K. Qian, X. B. Zhao, S. L. Morris-Natschke, Y. Liu, X. Nan, X. Tian and K. H. Lee, Med. Res. Rev., 2015, 35, 1-62.

12 Y. You, Curr. Pharm. Des., 2005, 11, 1695-1717.

13 A. Kamal, S. M. Ali Hussaini, A. Rahim and S. Riyaz, Expert Opin. Ther. Pat., 2015, 25, 1025-1034.

14 A. Kamal, A. Mallareddy, P. Suresh, V. L. Nayak, R. V. C. R. N. C. Shetti, N. S. Rao, J. R. Tamboli, T. B. Shaik, M. V. P. S. Vishnuvardhan and S. Ramakrishna, Eur. J. Med. Chem., 2012, 47, 530-545.

15 A. Kamal, J. R. Tamboli, M. V. P. S. Vishnuvardhan, S. F. Adil, V. L. Nayak and S. Ramakrishna, Bioorg. Med. Chem. Lett., 2013, 23, 273-280.

16 B. Meunier, Acc. Chem. Res., 2008, 41, 69-77.

17 A. M. Rimando, M. Cuendet, C. Desmarchelier, R. G. Mehta, J. M. Pezzuto and S. O. Duke, J. Agric. Food Chem., 2002, 50, 33453-33457.

18 E. S. Park, Y. Lim, J. T. Hong, H. S. Yoo, C. K. Lee, M. Y. Pyo and Y. P. Yun, Vasc. Pharmacol., 2010, 53, 61-67.

19 C. Stockley, P. L. Teissedre, M. Boban, C. Di Lorenzo and P. Restani, Food Funct., 2012, 10, 995-1007.

20 L. Pari and M. A. Satheesh, Life Sci., 2006, 79, 641-645.

21 A. M. Rimando, R. Nagmani, D. R. Feller and W. Yokoyama, J. Agric. Food Chem., 2005, 53, 3403-3407.

22 W. Nutakul, H. S. Sobers, P. Qiu, P. Dong, E. A. Decker, D. J. McClements and H. Xiao, J. Agric. Food Chem., 2011, 59, 10964-10970.

23 C. P. Ko, C. W. Lin, M. K. Chen, S. F. Yang, H. L. Chiou and M. J. Hsieh, Oral Oncol., 2015, 51, 593-601.

24 M. H. Pan, Y. S. Chiou, W. J. Chen, J. M. Wang, V. Badmaev and C. T. Ho, Carcinogenesis, 2009, 30, 1234-1242.

25 M. J. Ruiz, M. Fernández, Y. Picó, J. Mañes, M. Asensi, C. Carda, G. Asensio and J. M. Estrela, J. Agric. Food Chem., 2009, 57, 3180-3186.

26 P. Ferrer, M. Asensi, R. Segarra, A. Ortega, M. Benlloch, E. Obrador, M. T. Varea, G. Asensio, L. Jordá and J. M. Estrela, Neoplasia, 2005, 7, 37-47. 
27 C. M. Remsberg, J. A. Yanez, Y. Ohgami, K. R. Vega-Villa, A. M. Rimando and N. M. Davies, Phytother. Res., 2008, 22, 169-179.

28 L. Zhang, F. Chen, J. Wang, Y. Chen, Z. Zhang, Y. Lin and X. Zhu, RSC Adv., 2015, 5, 97816-97823.

29 L. Zhang, Z. Zhang, J. Wang, Y. Chen, F. Chen, Y. Lin and X. Zhu, RSC Adv., 2016, 6, 2895-2903.

30 L. Zhang, F. Chen, Z. Zhang, Y. Chen and J. Wang, Bioorg. Med. Chem. Lett., 2016, 26, 38-42.

31 J. H. Cho, W. G. Hong, Y. J. Jung, J. Lee, E. Lee, S. G. Hwang, H. D. Um and J. K. Park, Tumor Biol., 2015, 37, 1-11.

32 K. K. Mak, A. T. Wu, W. H. Lee, T. C. Chang, J. F. Chiou, L. S. Wang, C. H. Wu, C. Y. F. Huang, Y. S. Shieh, T. Y. Chao, C. T. Ho, G. C. Yen and C. T. Yeh, Mol. Nutr. Food Res., 2013, 57, 1123-1134.

33 K. Li, S. J. Dias, A. M. Rimando, S. Dhar, C. S. Mizuno, A. D. Penman, J. R. Lewin and A. S. Levenson, PLoS One, 2013, 8, e57542.
34 K. J. Huang and L. H. Sui, Med. Oncol., 2012, 29, 318-323. 35 S. Valastyan and R. A. Weinberg, Cell, 2011, 147, 275-292.

36 N. Khan and H. Mukhtar, Cancer Metastasis Rev., 2010, 29, 435-445.

37 J. Ren, L. Wu, W. Q. Xin, X. Chen and K. Hu, Bioorg. Med. Chem. Lett., 2012, 22, 4778-4782.

38 C. S. Lai, J. H. Lee, C. T. Ho, C. B. Liu, J. M. Wang, Y. J. Wang and M. H. Pan, J. Agric. Food Chem., 2009, 57, 10990-10998.

39 Y. S. Chiou, M. L. Tsai, K. Nagabhushanam, Y. J. Wang, C. H. Wu, C. T. Ho and M. H. Pan, J. Agric. Food Chem., 2011, 59, 2725-2733.

40 S. Paul, A. J. DeCastro, H. J. Lee, A. K. Smolarek, J. Y. So, B. Simi, C. X. Wang, R. Zhou, A. M. Rimando and N. Suh, Carcinogenesis, 2010, 31, 1272-1278.

41 L. Zhang, F. Chen, Z. Zhang, Y. Chen, Y. Lin and J. Wang, Bioorg. Med. Chem. Lett., 2016, 26, 4466-4471.

42 L. Zhang, Z. Zhang, F. Chen, Y. Chen, Y. Lin and J. Wang, Eur. J. Med. Chem., 2016, 123, 226-235. 